Berkala Ilmu Perpustakaan dan Informasi, Vol. 16, No. 2, Desember 2020, Hal. 239-252 DOI: 10.22146/bip.v16i1.151

ISSN 1693-7740 (Print), ISSN 2477-0361 (Online)

Tersedia online di https://journal.ugm.ac.id/v3/BIP

\title{
Peran lembaga informasi dalam era post-truth
}

\author{
Nurul Ivar Faturahmi ${ }^{1}$ \\ ${ }^{1}$ Departemen Ilmu Perpustakaan dan Informasi, \\ Fakultas Ilmu Pengetahuan Budaya, Universitas Indonesia, Depok, 16424, Indonesia \\ e-mail:nurul.ivar81@ui.ac.id
}

Naskah diterima: 25 Februari 2020, direvisi: 7 Oktober 2020, disetujui: 19 Oktober 2020

\begin{abstract}
ABSTRAK
Pendahulan. Peran lembaga informasi dalam era post-truth menjadi penting dalam mewujudkan masyarakat yang mandiri dan cakap dalam mengelola informasi. Artikel konseptual ini bertujuan melihat bagaimana peran lembaga informasi dalam menyikapi perilaku informasi masyarakat di era post-truth.

Metode penelitian. Metode dalam artikel ini menggunakan pendekatan kualitatif dengan jenis ulasan naratif (narrative review).

Data analisis. Analisis dilakukan dengan melakukan sintesis terhadap kajian literatur dan contoh kasus yang diambil dari beberapa pemberitaan mengenai dampak berita palsu yang menyebar di masyarakat.

Hasil dan pembahasan. Lembaga informasi perlu mengambil peran aktif dalam peningkatan kondisi masyarakat melalui pembangunan berbasis pengetahuan dan proses berbagi informasi, sehingga dapat menciptakan masyarakat yang cakap dalam menggunakan informasi, dan mampu mengevaluasi secara kritis kredibilitas dan kesesuaian sumber informasi.

Kesimpulan. Pada era post-truth, aspek psikologis hadir dalam ruang publik, di mana perilaku informasi seseorang menjadi lebih dominan dipengaruhi oleh dimensi emosional dan keyakinan pribadi. Hal ini semakin menunjukkan pentingnya keterampilan mengevaluasi sumber informasi dan berpikir kritis lebih jelas daripada era sebelumnya.
\end{abstract}

Kata kunci: lembaga informasi; perilaku informasi; post-truth; berita palsu; literasi informasi

\section{ABSTRACT}

Introduction. The role of information institutions in the post-truth era is important in creating an independent and competent society in dealing with information. This conceptual article aims to see the role of information institutions in responding to community information behavior in the post-truth era.

Data Collection Method. The method in this article uses a qualitative approach with the type of narrative review. Data Analysis. The analysis was carried out by synthesizing the literature and case studies from several reports discussing the impact of fake news spread in the community.

Results and Discussions. Information institutions need to take an active role in improving the conditions of society through knowledge-based development and information sharing processes, to create a community that is capable in using information and in evaluating the credibility and suitability of information sources.

Conclusion. In the post-truth era, psychological aspects become an important aspect, where one's information behavior becomes more dominantly influenced by emotional dimensions and personal beliefs. This increasingly shows the importance of skills in evaluating information sources and critical thinking more clearly than in previous eras.

Keywords: information institutions; information behavior; post-truth; fake news; information literacy 


\section{A. PENDAHULUAN}

Peran lembaga informasi dalam era posttruth menjadi krusial dalam mewujudkan masyarakat yang mandiri dan cakap dalam mengelola informasi. Hal ini karena perilaku informasi masyarakat pada abad ke-21 dipengaruhi oleh perangkat teknologi informasi yang cenderung membuat masyarakat berpikir instan. Kecenderungan berpikir instan tidak semata terjadi begitu saja. Adanya faktor 'efek samping' suatu teknologi sering tidak disadari oleh para penggunanya. Menurut Carr (2011) efek samping terbesar dari penggunaan teknologi pada manusia yaitu berubahanya cara berpikir manusia. Perubahan tersebut seperti sulitnya berkonsentrasi dan fokus, pendangkalan alam berpikir, dan budaya instan.

Pada era post-truth, perilaku informasi juga ditandai dengan kecenderungan pada aspek psikologis (Cooke, 2017b, 2018). Pengaruh emosi dan keyakinan pribadi lebih dominan dalam membentuk opini publik daripada data dan fakta yang objektif. Kasus Saracen pada 2017 lalu merupakan contoh bagaimana pesan kebencian dan hoaks yang berbau emosional dan bernuansa SARA memiliki sifat komersial dan terorgansir dalam membentuk opini publik melalui media sosial (BBC News Indonesia, 2017). Stieglitz \& Dang-Xuan (2013) menemukan bahwa pesan di media sosial Twitter yang bermuatan emosional cenderung di-retweet lebih sering dan lebih cepat dibandingkan dengan pesan yang netral.

Konsep post-truth telah ada selama dekade terakhir, namun menjadi sering digunakan setelah terjadinya referendum Brexit dan pemilihan presiden di Amerika Serikat pada 2016 (Lor, 2018; Oxford Dictionaries, 2016). Menurut Crăciun (2017) dan McIntyre (2018) berkembangnya teknologi informasi dan lingkungan digital membuat dampak pengaruh post-truth semakin melebar ke segala aspek. Salah satu fenomena akibat era post-truth yaitu maraknya berita palsu (fake news). Merebaknya berita palsu ditengarai merupakan dampak dari penggunaan media sosial sebagai media alternatif bagi masyarakat. Survei APJII 2018 mengungkapan bahwa alasan kedua terbesar masyarakat di Indonesia menggunakan internet yaitu untuk media sosial. Masyarakat saat ini menjadi lebih sering mengakses informasi dan berita dari media sosial atau aplikasi perpesanan yang tidak memiliki pengawasan yang jelas. Hal ini berbeda dari era sebelumnya di mana media tradisional seperti radio, televisi, dan koran menjadi arus utama kanal informasi berita bagi masyarakat. Keakuratan informasi dalam media tradisional terjaga karena adanya proses editorial berita yang jelas, sehingga berita yang diterima lebih terpercaya. Perubahan perilaku pencarian informasi masyarakat dalam mencari suatu berita dari media tradisional ke media sosial merupakan gejala dari minimnya tingkat literasi informasi dan media seseorang pada era post-truth. Di mana preferensi pribadi dan kelompok menjadi lebih utama dibandingkan dengan fakta yang terkandung dalam sebuah informasi.

Sifat berita dan apa yang orang terima sebagai berita juga bergeser ke arah pasar media yang berbasis pada keyakinan dan emosi. Kebenaran cerita tidak lagi penting, yang terpenting adalah bahwa kisah itu sejalan dengan apa yang ingin didengar seseorang. Berita palsu tidak lagi berarti, berita tanpa fakta atau fitnah, melainkan berita yang dianggap menyerang keyakinan seseorang yang sudah ada sebelumnya (Rochlin, 2017). Menurut Cooke (2017b) informasi tidak ada dalam ruang hampa melainkan dikelilingi dan dibentuk oleh konteks internal dan eksternal. Dia juga menekankan bahwa berbagai motivasi dan emosi mendasari konsumsi informasi seharihari. Pencarian informasi, pemilihan informasi, penghindaran informasi, dan penggunaan informasi (yang semuanya merupakan bagian dari rangkaian perilaku informasi) berkontribusi pada pemahaman kita tentang bagaimana informasi dikonsumsi setiap hari (Case \& Given, 2016) dan memberikan penjelasan tambahan mengapa orang rentan terhadap berita palsu.

Perhatian terhadap perilaku informasi masyarakat pada era post-truth menjadi tanggapan bagi lembaga informasi. Lembaga informasi dapat berperan dalam menghasilkan kontribusi sinergi budaya dalam menyebarkan objek dan konten informasi mereka, sehingga 
tercipta peningkatan kondisi masyarakat melalui pembangunan berbasis pengetahuan dan proses berbagi informasi (Smiraglia, 2014). Lembaga informasi yang dimaksud mencakup, perpustakaan, arsip, dan museum. Dalam perspektif yang lebih luas, lembaga informasi lainnya dapat berupa lembaga pemerintah dan non pemerintah yang mengelola, dan menyebarkan informasi terkait suatu isu atau topik tertentu.

Era post-truth di Indonesia ditandai dengan munculnya kasus penistaan agama oleh mantan Gubernur DKI Jakarta, Basuki Tjahaja Purnama pada 2016 (Taum, 2020). Rentetan berita palsu semakin merebak dan banyak bertebaran di masyarakat dipengaruhi oleh penggunaan media sosial pada masyarakat. Berita palsu yang disebarkan di media sosial menjadi viral dan menjadi sumber informasi yang banyak digunakan masyarakat sebagai referensi. Indonesia sangat rentan dengan konflik horizontal menyangkut SARA (suku, agama, ras, dan antargolongan). Merebaknya kasus berita palsu pada ranah politik yang menyangkut SARA menyebabkan kegaduhan dalam ketahanan nasional. Menurut Matahari Timoer anggota ICT Watch dalam laporan Franciska dan BBC Indonesia (18/4/2017) berbagai berita palsu bisa mempengaruhi pemilih yang emosional, "(Mereka) boleh jadi akan mempertahankan pilihannya berdasarkan sebaran kabar yang mengandalkan isu agama dan suku. Dalam kelompok ini, biasanya mereka tak terlalu mementingkan apa program kandidat, tetapi lebih pada siapa kandidatnya."

Berbagai diskusi tentang era post-truth telah menyebabkan fokus baru pada perilaku informasi masyarakat ke arah dimensi emosi (Cooke, 2017b, 2018; Crăciun, 2017; Laybats \& Tredinnick, 2016; Rochlin, 2017). Peran lembaga informasi menjadi krusial dalam mengedukasi masyarakat yang berbasis pada pengetahuan untuk dapat berpikir kritis terhadap informasi yang diterima. Salah satunya yakni perpustakaan, menurut Rubin (2016) perpustakaan sejak abad pertengahan ke delapan belas telah memiliki misi untuk membantu peningkatan diri individu dan pencarian kebenaran. Perpustakaan didirikan dengan asumsi bahwa informasi adalah alat untuk kebaikan sosial (Johnson, 2017). Di mana setiap orang memiliki hak yang sama dalam mengakses dan memperoleh informasi yang tepat dan akurat. Pustakawan perlu menyadari bahwa peran mereka dalam mendidik dan mengadvokasi pemikiran kritis kepada masyarakat sangat diperlukan. IFLA (2018) dalam pernyataannya mengenai berita palsu menggarisbawahi bahwa peran perpustakaan dalam membantu individu memanfaatkan potensi alat digital, termasuk melalui pemikiran kritis. Berpikir kritis merupakan keterampilan yang penting dalam menavigasi masyarakat informasi.

Penelitian konseptual ini bertujuan melihat bagaimana peran lembaga informasi dalam menyikapi perilaku informasi masyarakat di era post-truth. Artikel ini memberikan masukan kepada lembaga informasi dan para pekerja informasi untuk memahami dan mendiskusikan isu-isu dalam era post-truth. Lembaga informasi perlu melihatnya sebagai tantangan dan memberikan kontribusi peran dalam menangani isu tersebut sebagai bagian dari masyarakat informasi. Artikel ini berkontribusi pada perbaikan sudut pandang bagi pekerja informasi tentang hubungan antara informasi dan demokrasi di Indonesia. Serta masukan penelitian dalam bidang perilaku informasi yang berkenaan dengan dimensi psikologis.

\section{B. TINJAUAN PUSTAKA Lembaga Informasi}

Lembaga informasi dapat didefinisikan sebagai lembaga yang memiliki dan/ berbagi misi untuk melakukan preservasi, konservasi, dan menyebarkan objek informasi dan konten informatifnya (Dempsey, 2000). Menariknya, lembaga informasi juga disebut sebagai lembaga warisan budaya/lembaga memori yang umumnya mencakup perpustakaan, arsip, dan museum (Dempsey, 2000; Smiraglia, 2014). Sedangkan dalam perspektif yang lebih luas, lembaga informasi melibatkan penyebaran pengetahuan yang dipegang oleh budaya, yang berarti bahwa memperoleh, memelihara, dan menyebarluaskan artefak pengetahuan adalah fungsi utama sistemnya (Smiraglia, 2014). 
Lembaga informasi juga mencakup lembaga pemerintah dan non pemerintah yang mengelola, dan menyebarkan informasi terkait suatu isu atau topik tertentu.

Sejak dekade pertama abad kedua puluh satu, telah muncul konsensus bahwa perpustakaan, arsip, dan museum memiliki hubungan yang khusus. Setiap institusi memiliki tujuan yang sama untuk melestarikan warisan budaya masyarakatnya (Rubin, 2016). Menurut Dempsey (2000) perpustakaan, arsip, dan museum merupakan lembaga memori di mana koleksinya mengandung memori terhadap orang-orang, komunitas, lembaga, dan individu, warisan ilmiah dan budaya, produk sepanjang waktu, kerajinan tangan serta pembelajaran.

Agar berfungsi secara efektif, perpustakaan, arsip, dan museum mengandalkan infrastruktur pengetahuan yang luas yang mendukung kegiatan mereka. Infrastruktur pengetahuan terdiri dari komponen informasi, rekreasi, pendidikan, dan budaya masyarakat (Rubin, 2016). Smiraglia (2014) menyatakan bahwa terdapat banyak kesamaan antar lembaga informasi yang berhubungan dengan akar budaya mereka. Dia juga menyatakan secara sederhana bahwa budaya adalah basis pengetahuan yang umum bagi setiap kelompok orang.

Martin (2007) menjelaskan bahwa perpustakaan, arsip, dan museum mengumpulkan berbagai jenis barang dan koleksi. Perpustakaan mengumpulkan dokumen dari berbagai jenis (buku, jurnal, peta, dan sejenisnya), arsip mengumpulkan dokumen dari jenis tertentu (rekod yang berisi barang bukti tertentu), dan museum mengumpulkan bendabenda/objek dan artefak. Hal tersebut tampak jelas bahwa perpustakaan, arsip, dan museum adalah semua agen sosial yang secara kolektif bertanggung jawab untuk menjaga pengetahuan kolektif manusia, menjadikannya tersedia bagi semua orang untuk digunakan, dan mentransmisikannya kepada generasi mendatang.

\section{Apa itu Post-truth?}

Dua kamus besar bahasa Inggris, Cambridge Dictionary dan Oxford Dictionaries menjelaskan definisi post-truth berkaitan dengan keadaan atau situasi di mana orang lebih cenderung menerima argumen berdasarkan emosi dan keyakinan pribadi mereka daripada berdasarkan fakta. Fakta objektif menjadi kurang atau tidak berpengaruh lagi dalam membentuk opini publik (Cambridge Dictionary, 2018; Oxford Dictionaries, 2016).

Mengapa post-truth terjadi? Post-truth terjadi bukan karena seseorang tidak membantah fakta yang jelas atau mudah dikonfirmasikan tanpa alasan, melainkan melakukannya ketika hal itu menguntungkannya (Oxford Dictionaries, 2016). Menurut McIntyre (2018) menyatakan:

Ketika keyakinan seseorang terancam oleh 'fakta yang tidak nyaman,' kadang-kadang lebih baik untuk menantang fakta itu sendiri. Hal ini dapat terjadi pada tingkat sadar atau tidak sadar (karena terkadang orang yang ingin kita yakinkan adalah diri kita sendiri). Intinya, hubungan post-truth dengan fakta hanya terjadi ketika kita berusaha untuk menegaskan sesuatu yang lebih penting bagi kita daripada kebenaran itu sendiri. Jadi, post-truth merupakan bentuk supremasi ideologis, di mana para praktisi berusaha memaksa seseorang untuk percaya pada sesuatu apakah ada bukti yang baik untuk itu atau tidak, dan hal ini merupakan resep untuk dominasi politik.

Pada era post-truth keyakinan dan emosi pribadi menjadi faktor utama dalam mencari 'kebenaran' dalam sebuah informasi (Cooke, 2017b, 2018; Laybats \& Tredinnick, 2016). Kebenaran itu sendiri menjadi tidak penting, masyarakat cenderung menentukan informasi yang ingin diterimanya berdasarkan preferensi pribadinya (Crăciun, 2017; Johnson, 2017; Rochlin, 2017). Pada era post-truth berita palsu dikemas menjadi sesuatu yang dapat menyentuh emosi khalayak, digantikan oleh konten yang menarik pada tingkat yang lebih emosional, sehingga hal tersebut mempengaruhi keputusan yang dilakukan pembaca informasi (Laybats \& Tredinnick, 2016; Rochlin, 2017). Misalnya, 
informasi mengenai SARA (suku, agama, ras, dan antargolongan) mudah menyulut emosi dan rentan terhadap konflik horizontal di berbagai negara yang multikultural seperti di Indonesia.

Kontradiksi drastis dalam keyakinan merupakan lambang dari masyarakat post-truth saat ini, di mana fakta-fakta dari masalah adalah kepentingan sekunder dari pendapat yang mengambang bebas. Hal ini ditandai dengan kebutaan yang disengaja terhadap bukti, ketidakpercayaan terhadap otoritas, dan membandingkan ke argumen berbasis emosional yang sering berakar pada ketakutan atau kecemasan pribadi (Laybats \& Tredinnick, 2016).

\section{Perilaku Informasi}

Perilaku informasi mencakup pencarian informasi serta totalitas perilaku tidak disengaja atau kebetulan lainnya (seperti melihat sekilas atau menemukan informasi), serta perilaku yang bertujuan tidak melibatkan pencarian, seperti secara aktif menghindari informasi dan bagaimana berinteraksi dengan informasi (Bates, 2017; Case \& Given, 2016). Perilaku informasi juga mencakup konteks yang lebih luas tentang bagaimana individu 'menangani' informasi dalam kehidupan mereka, sehingga memperhitungkan situasi, waktu, pengaruh, budaya, geografi, dan elemen kontekstual lainnya (Case \& Given, 2016).

Perilaku informasi merupakan cara persepsi individu melihat, mencari, memahami, dan menggunakan informasi dalam berbagai konteks kehidupan, baik dalam konteks sosial maupun dalam praktik yang terintegrasi dengan nilai-nilai budaya (Bates, 2017; Case \& Given, 2016). Dalam kesehariannya, manusia sadar atau tidak, selalu berkutat dengan informasi. Bagaimana mereka menangani informasi tersebut bergantung dengan berbagai aspek baik internal dan eksternal dari informasi itu sendiri dan manusianya (Cooke, 2017b). Contoh kasus ketika seseorang hendak pindah tempat tinggal dari satu kota ke kota lainnya, individu tersebut akan mencari tahu mengenai kondisi tempat lingkungan baru yang akan ditinggalinya, baik informasi geografis, kesehatan, pendidikan, transportasinya, dan sebagainya. Informasi juga mencakup cerita-cerita mengenai daerah tersebut, berbagai kondisi dalam konteks sosial budaya, situasi terkini, dan berbagai hal baik secara langsung dan tidak langsung yang berkaitan mengenai kota tempat yang akan dituju oleh individu tersebut.

Pada abad ke-21 di mana internet menjadi media utama dalam sebaran informasi menjadikan pandangan baru bahwa internet itu sendiri bisa jadi merupakan metamorforsis dari perilaku informasi dan bagaimana pandangan dan cara berpikir manusia telah banyak berubah (Bates, 2017; Carr, 2011). Sumber informasi yang sebelumnya hanya dalam jenis tercetak dan terdapat di lokasi tertentu saja, kini dengan lahirnya internet membuat rintangan dalam akses informasi menjadi lebih longgar (Case \& Given, 2016). Penciptaan sumber informasi kini tidak hanya dimiliki oleh lembaga dan institusi informasi saja, melainkan tiap individu dengan berbagai saluran seperti media sosial, blog, website, dan sebagainya, memungkinkan penciptaan, penyebaran, dan pengaksesan informasi tersebar bagi orang-orang tertentu (Cooke, 2017b; Smiraglia, 2014). Case dan Given (2016) menambahkan bahwa dengan cara yang mirip dengan kemunculan World Wide $W e b$, pandangan tentang perilaku informasi menjadi lebih terintegrasi dan kurang didikte oleh sumber dan institusi/lembaga informasi.

Studi perilaku informasi mengeksplorasi konteks yang lebih luas dari pengalaman individu dengan informasi (Bates, 2017; Case \& Given, 2016; Deng \& Xia, 2020). Faktanya informasi belaka tidak dapat memuaskan kebutuhan manusia. Terdapat faktor lain yang mempengaruhi pertimbangan seseorang yang pada akhirnya memutuskan apakah suatu informasi tersebut penting atau tidak (Case \& Given, 2016). Misalnya, penting memahami adanya kebutuhan dasar dan skala prioritas pada tiap jenis informasi. Jumlah pencarian informasi mengenai liburan mungkin lebih banyak, namun informasi mengenai pengobatan penyakit kanker atau leukimia bisa jadi lebih penting (Tan \& Goonawardene, 2017; Wahyuni, 2019).

Menurut Case dan Given (2016) terdapat tiga sumber informasi dalam literatur perilaku informasi: 
Pertama, sumber formal yang mencakup publikasi tercetak seperti buku, ensiklopedia, koran harian, dan para ahli dalam subjek tertentu. Kedua, sumber informal mencakup teman, kolega, keluarga, budaya popular lainnya seperti acara televisi, musik di radio, grup diskusi di internet, media sosial, dan banyak lainnya. Ketiga, informasi interpersonal yang disebut juga dengan pengetahuan dan memori, yang merupakan masukan dari pengalaman-pengalaman seseorang atau kelompok sebelumnya dalam kehidupan, yang ternyata relevan dengan tugas dan situasi yang dihadapi.

Namun, dalam perilaku informasi, gagasan dalam memilih input sumber informasi tersebut (apa pun alasannya) juga dapat dikatakan sebagai bentuk penghindaran informasi (information avoidance). Penghindaran informasi menurut Sweeny, Melnyk, Miller, \& Shepperd (2010) merupakan perilaku apa pun yang dimaksudkan untuk mencegah atau menunda perolehan informasi yang tersedia tetapi berpotensi tidak diinginkan. Penghindaran informasi dapat aktif (misalnya dengan meminta seseorang untuk tidak mengungkapkan informasi) atau pasif (misalnya dengan tidak menanyakan kepada seseorang pertanyaan yang akan mengungkapkan informasi). Namun, Case dan Given (2016) berpendapat bahwa penghindaran informasi juga disebabkan oleh sekelompok orang tidak mendapatkan informasi yang sama dengan kelompok lainnya, hal ini karena adanya kesenjangan pengetahuan atau disebut juga kelompok yang miskin informasi.

\section{METODE PENELITIAN}

Metode dalam penelitian ini menggunakan pendekatan kualitatif dengan jenis ulasan naratif (narrative review). Ulasan naratif merupakan jenis tinjauan yang berguna dalam mengumpulkan sejumlah literatur dalam bidang subjek tertentu dan mensintesisnya. Tujuannya adalah untuk memberikan pembaca latar belakang yang komprehensif, mengidentifikasi dan menggambarkan suatu masalah yang diminati saat ini, dan memahami pengetahuan atau menyoroti pentingnya penelitian baru tersebut (Demiris, Oliver, \& Washington, 2019; Paré \& Kitsiou, 2016). Langkah-langkah dalam melakukan ulasan naratif yaitu melakukan pencarian, mengidentifikasi kata kunci, meninjau isi abstrak dan artikel, serta meringkas dan mensintesis temuan dari artikel dan mengintegrasikannya ke dalam tulisan (Demiris et al., 2019).

Kegiatan penelitian dilakukan dengan pencarian terhadap literatur-literatur dan berita mengenai lembaga informasi, perilaku informasi, dan post-truth. Literatur dicari pada basis data ProQuest dan Scopus dengan menggunakan kata kunci "information institution", "post-truth", "information behavior", "emotional" dan "Indonesia". Kata kunci tersebut digunakan satu sama lainnya untuk mengumpulkan bahan literatur. Selain itu, Google Scholar juga digunakan untuk menelusur literatur dan sitasi yang relevan. Analisis data dilakukan dengan meringkas dan mensintesis temuan pada literatur dan kasus pada berita palsu. Hasil temuan tersebut disajikan dalam bentuk konsep tentang bagaimana peran lembaga informasi dalam menyikapi perilaku informasi masyarakat di era post-truth. Kasus diambil berdasarkan pemberitaan mengenai dampak berita palsu yang menyebar di masyarakat dan bagaimana hal tersebut terjadi.

\section{HASIL DAN PEMBAHASAN \\ Disinformasi dan Lembaga Informasi di Era Post-truth}

Dalam era post-truth terdapat dua dimensi kognitif dalam perilaku informasi yang dapat dimasuki oleh berita palsu, yaitu disinformasi dan misinformasi (Cooke, 2018). Disinformasi (disinformation) adalah suatu bentuk informasi yang tidak benar secara sengaja dengan maksud tertentu. Menurut Oxford Dictionary, disinformasi merupakan informasi palsu yang dimaksudkan untuk menyesatkan, terutama propaganda yang dikeluarkan oleh organisasi pemerintah kepada kekuatan saingan atau media. Misinformation dapat didefinisikan sebagai informasi yang salah atau tidak akurat, 
terutama yang sengaja dimaksudkan untuk menipu, tetapi juga dapat dikategorikan sebagai informasi yang tidak pasti, tidak jelas, atau ambigu (Cooke, 2017a; Oxford Dictionary, 2018).

Kecenderungan untuk menghakimi suatu informasi yang diterima berdasarkan preferensi pribadi menjadikan fakta objektif menjadi tidak penting lagi. Kasus-kasus dengan preferensi politik pribadi di Indonesia merupakan contoh di mana masyarakat telah memasuki era posttruth yang kronis, di mana segala hal ditarik pada dua versi kebenaran yang digeneralisasi sebagai pro dan kontra. Fenomena post-truth merupakan suatu yang kompleks. Hal ini bukanlah masalah defisit atau kekurangan informasi atau pengetahuan, tetapi masalah epistemologi sosial kontemporer, apa yang kita pahami dengan fakta, bagaimana orang menjadi percaya apa yang mereka anggap benar, dan bagaimana hal ini dapat membentuk perilaku mereka (Lor, 2018). Bukanlah hal yang baru nilai kebenaran dipertanyakan. Tiga puluh lima tahun yang lalu, teoretikus kontroversial Baudrillard mengatakan bahwa "we live in a world where there is more and more information, and less and less meaning" (1994, as cited in Laybats \& Tredinnick, 2016).

Pada tahun 2013, Perpustakaan Nasional Singapura meluncurkan kampanye nasional S.U.R.E (Source, Understand, Research, Evaluate) dalam rangka mempromosikan pentingnya pencarian informasi. Kampanye literasi informasi ini dilakukan dalam skala nasional oleh Perpustakaan Nasional Singapura. Kampanye S.U.R.E menekankan pada bagaimana melihat sumber informasi apakah terpercaya, memahami yang dibaca dan mencari tahu kejelasannya, melakukan penelitian untuk menggali lebih dalam mengenai suatu informasi dan melampaui sumber awal, dan bagaimana mengevaluasi dengan menemukan keseimbangan dan penilaian secara adil (National Library Board, 2013). Kampanye S.U.R.E yang dilakukan Perpustakaan Nasional Singapura merupakan contoh bagaimana perpustakaan berinisiasi dalam rangka mengedukasi masyarakat melawan berita palsu secara berkelanjutan.
Bagaimana dengan di Indonesia? Agaknya literasi sendiri masih merupakan pekerjaan rumah yang sangat besar. Bukan hanya sekedar masalah baca tulis, tinggi rendah minat baca, tetapi orang yang berpendidikan dan lembaga negara pun kadang luput dari literasi itu sendiri. Salah satu contoh buruknya kualitas literasi ditunjukkan dengan rendahnya kemampuan menguasai informasi secara menyeluruh. Beberapa kasus diantaranya melibatkan pejabat dan tokoh publik yang menyebarkan video ahistoris dalam rangka menyambut kemerdekaan RI ke-74, taggar \#74thIndonesiaMerdeka digunakan dalam topik tersebut. Video yang telah dihapus ini menunjukkan rendahnya literasi informasi pejabat publik kita dalam melakukan penyebaran informasi yang tidak akurat. Video yang sejatinya bermaksud ingin mengobarkan sikap persatuan tanpa separatisme itu pun minim dengan penggalian data sejarah. Pembuat gagal dalam menerjemahkan terminologi separatisme dan kasus pelanggaran HAM berat. Video yang sempat beredar di media sosial itu mendapat kritikan dari Direktur Yayasan Lembaga Bantuan Hukum Indonesia (YLBHI) Asfinawati. Ia menilai, "Bekraf sebagai salah satu lembaga negara tak sensitif terhadap korban di beberapa peristiwa yang disebut dalam video" (Nathaniel, 2019). Menurut Johnson (2017) banyak orang yang sangat terpelajar dengan keterampilan menggunakan informasi secara efektif untuk mencapai tujuan tertentu, namun tidak ada yang tampak tertarik untuk mengevaluasi informasi dan sumbersumbernya secara kritis. Padahal menurutnya, analisis dan pemikiran kritis adalah pertahanan yang lemah dan mudah dibanjiri oleh semburan pendapat dan emosi liar.

Hal tersebut merupakan contoh kasus bahwa disinformasi telah merasuki ranah lembaga negara yang semakin menghawatirkan di Indonesia. Hal-hal yang berkaitan dengan SARA dan HAM menjadi hal yang berpotensi dalam konflik horizontal di Indonesia. Menurut Johnson (2017) pandangan yang fanatik terhadap suatu kelompok sering mempengaruhi individu pada kelompok tersebut. Ketika individu/kelompok mempercayai sesuatu, dan 
bahwa sesuatu itu terbukti salah, namun terus mempercayainya-bahkan terdapat bukti yang sangat kuat-hal tersebut menunjukkan preferensi keyakinan individu/kelompok tersebut. Percaya pada fakta yang tidak terbukti, membuktikan bahwa individu/kelompok tersebut mengabdi pada pandangan fanatik komunitas dan dunianya sendiri.

Selain dalam ranah politik dan SARA, kasus berita palsu juga mewabahi informasi penting lainnya seperti kebencanaan. Kasus tersebut menyebabkan pemanggilan peneliti BPPT oleh polisi dikarenakan informasi yang tersebar telah menjadi berita palsu yang meresahkan masyarakat. Seperti yang dituliskan dalam laporan Artharini dan BBC Indonesia (9/4/2018), terdapat hasil kajian potensi tsunami yang dilakukan oleh peneliti BPPT Dr. Widjo Kongko menyebutkan bahwa terdapat potensi tsunami $57 \mathrm{~m}$ dari hasil modeling (simulasi model) komputer di Jawa bagian Barat. Namun, media online lain mengutip pernyataan Dr. Widjo dengan kata prediksi, di mana hal tersebut (kata potensi dan prediksi) memiliki perbedaan makna yang jauh. Hal tersebut menyebar menjadi berita palsu yang menyebabkan kepanikan pada masyarakat di kawasan Pandeglang, Jawa Barat. Kasuskasus berita palsu tersebut menjadi contoh betapa rentannya masyarakat Indonesia dengan berita palsu yang beredar tanpa diiringi dengan pengedukasian yang benar dari pihak yang berwajib. Perkembangan teknologi dan informasi yang tidak dibarengi oleh kemampuan dalam mengelola informasi yang baik menambah ringkihnya keadaan masyarakat Indonesia dalam menanggapi suatu informasi.

Data survei Asosiasi Penyelenggara Jasa Internet Indonesia (APJII) tahun 2018 menunjukkan pengguna internet di Indonesia lebih dari 171 juta jiwa (APJII, 2018). Pengguna internet yang terus bertambah di Indonesia tidak berbanding lurus dengan indeks aktivitas literasi membaca (alibaca) pada masyarakat. Hasil penelitian terhadap indeks alibaca nasional pada tahun 2019 menunjukkan aktivitas literasi yang rendah pada masyarakat di Indonesia (Solihin, Utama, Pratiwi, \& Novirina, 2019). Rendahnya indeks literasi masyarakat ini berdampak pada rendahnya kemampuan dalam mengevaluasi sumber informasi secara kritis. Menurut Solihin et al. (2019) kebiasaan membaca masyarakat yang sangat kurang itu tampak dari minimnya akses pada sumber-sumber literasi baik cetak maupun elektronik. Hal ini menunjukkan bertambahnya jumlah pengguna ke internet tidak semata-mata menjadikan budaya membaca juga meningkat. Tingginya jumlah pengguna internet yang tidak dibarengi dengan kemampuan literasi dapat menjadi celah bagi masuknya disinformasi dan misinformasi di masyarakat. Laporan survei Daily Social 2018 menyebutkan tingginya jumlah responden yang tidak yakin memiliki kepiawaian dalam mendeteksi berita (44.19\%) (Daily Social, 2018). Disinilah peran bagi lembaga informasi yang dapat meningkatkan keterampilan informasi dan pengetahuan masyarakat, menyediakan sumber yang otoritatif, dan berperan aktif di masyarakat agar mampu menavigasi kebutuhan informasinya.

Lembaga informasi seperti perpustakaan, arsip, dan museum sejatinya merupakan lembaga strategis dalam melawan berita palsu dan kemiskinan informasi dalam masyarakat. Lembaga informasi melibatkan penyebaran pengetahuan yang dipegang oleh suatu budaya, yang berarti bahwa memperoleh, memelihara, dan menyebarluaskan artefak pengetahuan adalah fungsi utama dari sistem lembaga informasi (Smiraglia, 2014). Menurut Johnson (2017) perpustakaan telah berusaha keras untuk memberikan informasi yang andal, tetapi dalam perang informasi ini, fakta itu sendiri telah terbukti sebagai teknologi yang usang. Lalu apa yang dapat perpustakaan dan pustakawan lakukan dalam era post-truth ini?

Rochlin (2017) menyarankan empat implikasi untuk perpustakaan. Pertama, perpustakaan perlu merevisi pemahamannya konsep dan retorika kita tentang hubungan antara perpustakaan, informasi dan demokrasi. Kedua, karena masalahnya jauh lebih besar daripada perpustakaan, melalui kemitraan dengan pihak lain seperti pendidik, jurnalis, dan media, pustakawan dapat memberikan kontribusi paling berguna, seperti menyajikan sumber-sumber yang otoritatif. Ketiga, 
perpustakaan harus mengerahkan kekuatan yang mereka miliki sebagai sumber daya komunitas non-partisan yang tepercaya, dan mereka harus memelihara kepercayaan ini. Keempat, kepercayaan pada perpustakaan terkait dengan keteguhan jangka panjang mereka di tengah peristiwa terkini. Perpustakaan memiliki horizon waktu yang lama, sehingga dapat sedikit demi sedikit melakukan perbaikan. Hal ini amat berharga, karena tidak ada perbaikan yang cepat.

Dalam konteks perpustakaan di Indonesia, hal yang dapat dilakukan di tataran praktis yaitu, pertama, perpustakaan umum harus mengubah pola pikir dan berperan aktif dengan melakukan 'jemput bola' untuk mengedukasi masyarakat. Perpustakaan dapat berperan aktif dan teribat dalam kegiatan masyarakat disekitarnya, sehingga terjalin kedekatan antara perpustakaan dengan masyarakat. Perpustakaan dapat mengedukasi masyarakat tidak hanya untuk meningkatkan budaya membaca. Namun juga dapat meningkatkan keahlian literasi informasi masyarakat untuk menyelesaikan berbagai kendala informasi bagi kehidupan sehariharinya. Sehingga terbentuklah rasa kebutuhan akan kehadiran perpustakaan bagi masyarakat. Dengan horizon waktu yang panjang, perpustakaan umum dapat berkolaborasi dengan sekolah-sekolah disekitarnya, komunitas-komunitas hobi, atau terlibat dalam kegiatan karang taruna dan ibu-ibu Pembina Kesejahteraan Keluarga (PKK) di lingkungannya. Sehingga diharapkan peran perpustakaan umum dapat membantu kualitas hidup masyarakat disekitarnya serta cakap dalam mengelola informasi. Pada tingkat individu, upaya aktif perpustakaan untuk membangun media yang relevan dan literasi informasi juga dapat membantu mendukung masyarakat untuk mengevaluasi secara kritis kredibilitas dan kesesuaian sumber informasi.

Kedua, peran perpustakaan sekolah dan perguruan tinggi khususnya, dengan mendorong adanya kurikulum dan pengajaran mengenai literasi informasi dan media. Sehingga diharapkan para pengguna dapat menjadi pembelajar sepanjang hayat yang melek informasi. Perpustakaan perguruan tinggi khususnya, perlu menyediakan sumber-sumber informasi yang mencakup berbagai sudut pandang dengan sumber yang otoritatif. Hal tersebut diharapkan menjadikan perpustakaan sebagai sumber informasi yang non-partisan karena mampu memberikan akses ke semua jenis bacaan dari berbagai ideologi dan mendukung kemerdekaan akademis. IFLA (2018) dalam pernyataan mengenai berita palsu menyatakan bahwa perpustakaan memiliki komitmen kelembagaan dan etika untuk membantu masyarakat mengakses informasi yang andal dan otentik. Peran ini sama pentingnya di masa ketika berita palsu adalah fenomena yang tampaknya berkembang.

Lalu bagaimana dengan peran museum dalam era post-truth? Dalam penelitian yang dilakukan de los Santos, Smith, dan Cohen (2018) museum dapat berkontribusi dalam isuisu sosial dan berita palsu. Museum dapat membuat konten dan acara yang berfungsi sebagai model untuk mengembangkan pendidikan museum di masa depan dan program seputar masalah sosial kontroversial yang sedang berkembang untuk kebutuhan masyarakat. Selain itu, museum dapat menjadi tempat inspirasi dan menjadi bagian keterlibatan publik dari apa yang mereka lakukan, museum juga menyimpan bukti dan pencipta pengetahuan tersebut.

Peran museum-museum yang ada di Indonesia dalam era post-truth dapat berkontribusi dalam penciptaan konten informasi dari objek yang mereka milki. Adanya bentuk virtual dalam layanan meseum akan membantu dan memudahkan masyarakat dalam mengakses informasi kebendaan yang ada di museum. Museum dapat mengedukasi masyarakat dengan isu yang mengedepankan bukti otentik dari peristiwa-peristiwa sejarah dan artefak-artefak yang ada.

Arsip juga diperlukan dalam era post-truth ini, tidak hanya mendukung dengan bukti otentik, namun peran arsip justru lebih luas dalam menghadapi berita palsu. Commisso (2017) menyatakan:

Banyak profesi informasi berfokus pada pemberantasan berita palsu melalui 
pendidikan literasi media, pengembangan kebijakan, dan kemajuan dalam teknologi pencarian dan media sosial, profesi arsip memiliki tugas yang sedikit berbeda, yaitu mengevaluasi bagaimana berita palsu dapat dilestarikan. Proliferasi berita palsu menandai pergeseran budaya yang signifikan dalam informasi, politik, dan identitas, serta merupakan retrospektif yang berharga tentang bagaimana kita mengkonsumsi dan berbagi media serta menilai dampak kolektifnya terhadap masyarakat. Tetapi pengarsipan berita palsu adalah upaya yang kompleks, terutama ketika harus memastikan bahwa arsip menyertakan konteks yang cukup untuk membantu peneliti di masa depan dapat menafsirkan informasi tersebut dan menjadi sumber daya utama untuk memahami dampak media terhadap budaya dan perilaku manusia.

Di Indonesia peran lembaga informasi seperti perpustakaan, arsip, dan museum dapat berkolaborasi dalam menyajikan objek dan konten informasi yang seimbang dalam mewujudkan prinsip demokrasi yang sehat di masyarakat. Perpustakaan dapat berperan dalam meningkatkan literasi informasi dan berpikir kritis dalam upaya pembelajaran sepanjang hayat bagi masyarakat. Arsip dapat berperan dalam menyediakan bukti otentik dari rekod dan dokumen jenis tertentu yang dapat mendukung suatu informasi yang sahih, termasuk mempertimbangkan pengarsipan berita palsu yang dapat digunakan di masa akan datang. Adapun museum berperan sebagai lembaga informasi yang dapat menyajikan konten berupa benda, objek, dan artefak yang dapat menjadi bukti pendukung dari suatu pengetahuan yang lebih interaktif kepada masyarakat.

Lembaga informasi perlu memposisikan diri sebagai komandan dalam perang informasi ini. Lembaga informasi perlu menyuarakan pentingnya mengedepankan aspek pengetahuan berbasis data yang objektif dalam pembuatan dan penyebaran informasi. Masyarakat Indonesia, secara kultural adalah masyarakat dengan budaya lisan. Budaya membaca belum menjadi bagian dari kesehariannya. Survei APJII 2018 mengungkapkan bahwa konten internet yang sering dikunjungi masyarakat yaitu dalam bentuk tontonan film/video (45.30\%). Disini lembaga informasi di Indonesia perlu berinovasi dalam menyajikan informasi yang mereka miliki dalam berbagai format media. Dengan bertambahnya jumlah pengguna internet, perpustakaan dapat membuat kemas ulang informasi dengan menggunakan bergam media sosial baik secara audio visual seperti Youtube, dalam bentuk audio podcast, maupun dalam bentuk infografis yang kesemuanya itu dapat mendukung kebiasaan perilaku informasi masyarakat di era post-truth ini. Begitupun dengan arsip, dapat berkontribusi membuat film film pendek berdasarkan data arsip yang otentik. Museum dapat membuat galeri dalam bentuk virtual augmented reality yang dapat memberikan pengalaman informasi yang baru.

\section{Sadar akan Proses Psikologis dalam Perilaku Informasi}

Pengetahuan adalah kekuatan. Lembaga informasi ada sebagai upaya peningkatan kondisi masyarakat melalui pembangunan berbasis pengetahuan (Smiraglia, 2014). Ketika kita sadar bahwa kita secara psikologis diprogram untuk memercayai informasi terlebih dahulu, menjadi lebih mudah untuk memasukkan skeptisisme ke dalam analisis informasi/berita kita. Hal ini membuat lebih mudah untuk menolak berita palsu jika kita awalnya dapat menerima bahwa itu mungkin berita palsu. Lebih mudah untuk mengabaikan kesalahan informasi di awal jika kita tahu otak kita memiliki kecenderungan untuk mempertahankannya. Burkhdat (2017) menjelaskan kecenderungan psikologis yang dapat menyebabkan masyarakat mempercayai berita palsu, dan mengingatkan mereka tentang kecenderungan itu secara berkala, dapat memberi masyarakat sarana untuk memeriksa berita itu secara lebih kritis.

Dalam era post-truth perilaku pencarian informasi berlandaskan pada emosi yang menyebabkan terjadinya information avoidance, yaitu penghindaran informasi, 
seperti "saya tidak mau mendengar informasi dari saluran berita tertentu karena tidak suka", dan setiap orang memiliki perasaan dan pertimbangan sendiri terhadap sumber informasi yang mereka pilih (Cooke, 2017a). Dalam media sosial, setiap orang bebas memilih siapa atau sumber apa yang mereka ingin ikuti sebagai sumber informasi mereka. Penting untuk mengetahui dan menjelaskan kepada masyarakat bahwa efek gelembung filter (filter bubble) dari apa yang diikuti masyarakat adalah bentuk dari penggunaan konten informasi yang hanya memperkuat nilai, pendapat, dan keyakinan pribadi mereka (Laybats \& Tredinnick, 2016).

Informasi dapat dikemas dari berbagai sudut pandang yang berbeda dan menciptakan penangkapan yang baru terhadap peristiwa yang terjadi. Hal ini menjadi penting diketahui bagi para pekerja informasi dalam mendidik masyarakat agar menyadari proses psikologis dalam perilaku pencarian informasi baik di media sosial maupun media lainnya.

Berpikir kritis merupakan salah satu keterampilan dalam masyarakat informasi, dan misi perpustakaan adalah untuk mendidik dan mengadvokasi pentingnya hal tersebut kepada para pemustakanya (IFLA, 2017). Kovach dan Rosenstiel (2011, as cited in Cooke, 2017b) mengemukakan bahwa konsumen informasi perlu mengembangkan dan mempertahankan cara skeptis untuk mengetahui pembaca dan pendengar tidak boleh secara buta menerima apa yang mereka lihat dan dengar. Tetapi harus terus-menerus mempertanyakan informasi yang disajikan kepada mereka, bahkan jika itu disajikan oleh sumber yang mereka pikir mereka percayai.

Menurut Cooke (2017b) dalam berpikir kritis sikap yang diperlukan adalah bersikap terbuka, mengajukan pertanyaan (memiliki rasa ingin tahu), menghargai fakta, menimbang bukti, dan melakukan uji tuntas dalam mencari informasi akan memungkinkan masyarakat informasi menjadi kritis terhadap sumber informasi, menjadi konsumen kritis, dan menjadi tahan terhadap rekayasa yang sering disajikan dalam sumber media.
Literasi informasi yang berfokus pada beragam media tampaknya menjadi salah satu pilihan untuk memungkinkan masyarakat mencegah pengaruh buruk dari berita palsu. Thomas Jefferson pernah mengatakan "Don't believe everything you read on the Internet" (McIntyre, 2018), dan peringatan hari ini menjadi, "Don't believe everything you see, hear, or read on social media."(Burkhardt, 2017). Berpikir kritis yang sehat dan evaluasi yang ketat terhadap sumber-sumber informasi, penulis, penerbit, dan konten adalah kunci untuk menghindari berita palsu (Burkhardt, 2017; McIntyre, 2018).

\section{E. KESIMPULAN}

Era post-truth membuat masyarakat menerima argumen berdasarkan emosi dan keyakinan mereka daripada berdasarkan fakta. Masyarakat perlu menyadari akan penghidaran informasi yang dilakukan baik secara aktif maupun pasif dalam perilaku informasi mereka akibat efek era post-truth. Tugas lembaga informasi menjadikan masyarakat berpengetahuan luas dengan memberikan akses informasi yang andal dan berkualitas kepada semua golongan. Sehingga dapat mengecilkan jurang kesenjangan pengetahuan dan kemiskinan informasi pada kelompok tertentu. Era post-truth menjadi peluang baik bagi lembaga informasi (perpustakaan, arsip, dan museum) untuk melebarkan pengaruhnya dalam rangka mencerdaskan kehidupan berbangsa, bernegara, dan demokrasi yang sehat. Lembaga informasi wajib berupaya menyediakan akses ke berbagai sudut pandang dengan cermat mengumpulkan koleksi yang mencakup perspektif dari semua ujung spektrum politik dan dari semua isu-isu yang kontroversial. Lembaga informasi dan pekerja informasi harus bersikeras bahwa mereka memberikan informasi yang berkualitas dan mencakup semua sudut pandang, bahkan jika masyarakat memilih untuk tidak menggunakannya. 


\section{DAFTAR PUSTAKA}

APJII. (2018). Penetrasi \& profil perilaku pengguna internet Indonesia: Survei 2018. Jakarta: Asosiasi Penyelenggara Jasa Internet Indonesia.

Artharini, I., \& BBC Indonesia. (2018). "Potensi tsunami 57 meter": Bisakah polisi mempidanakan penelitian ilmiah? Retrieved December 23, 2018, from https://www.bbc.com/indonesia/trensosial43696823

Bates, M. J. (2017). Information behavior. In J. D. McDonald \& M. Levine-Clark (Eds.), Encyclopedia of Library and Information Science (4th ed.). Boca Raton: CRC Press. doi:10.1081/E-ELIS4

BBC News Indonesia. (2017). Kasus Saracen: Pesan kebencian dan hoax di media sosial "memang terorganisir" - BBC News Indonesia. Retrieved December 25, 2018, from https://www.bbc.com/indonesia/ trensosial-41022914

Burkhardt, J. M. (2017). How can we help our students? Library Technology Reports, 53(8), 29-33. Retrieved from https://journals.ala.org/index.php/ltr/articl e/view/6501

Cambridge Dictionary. (2018). Post-Truth | meaning in the Cambridge English Dictionary. Retrieved December 25, 2018, from https://dictionary.cambridge.org/ dictionary/english/post-truth

Carr, N. (2011). The shallows: What the internet is doing to our brains. New York: W. W. Norton \& Company.

Case, D. O., \& Given, L. M. (2016). Looking for information: A survey of research on information seeking, needs, and behavior (4th ed.). Bingley: Emerald Group Publishing Limited.

Commisso, C. (2017). The post-truth archive:considerations for archiving context in fake news repositories. Preservation, Digital Technology \& Culture, 46(3), 99-102. doi:10.1515/pdtc2017-0010
Cooke, N.A. (2017a). Post-truth: Fake news and a new era of information literacy. programming librarian. ALA's Public Programs Office. Retrieved from http://programminglibrarian.org/learn/post - truth - fake-new s-and-new - era information-literacy

Cooke, N. A. (2017b). Posttruth, truthiness, and alternative facts: Information behavior and critical information consumption for a new age. The Library Quarterly, 87(3), 211-221. doi:10.1086/692298

Cooke, N. A. (2018). Fake news and alternative facts: Information literacy in a post-truth era. Chicago: ALA Editions.

Crăciun, A. (2017). Post truth. contemporary paradigms in framing information. Library and Information Science Research, (21), 75-81.

Daily Social. (2018). Hoax distribution through digital platforms in Indonesia 2018. Retrieved from https://dailysocial.id/post/ laporan-dailysocial-distribusi-hoax-dimedia-sosial-2018

de los Santos, T. M., Smith, E., \& Cohen, M. (2018). Targeting truth: How museums can collaboratively address social issues. Journal of Museum Education, 43(2), 104-113. doi:10.1080/10598650.2018. 1457842

Demiris, G., Oliver, D. P., \& Washington, K. T. (2019). Defining and analyzing the problem. In Behavioral Intervention Research in Hospice and Palliative Care (pp. 27-39). London: Academic Press. doi:10.1016/B978-0-12-814449-7.00003$\mathrm{X}$

Dempsey, L. (2000). Scientific, industrial, and cultural heritage: a shared approach: a research framework for digital libraries, museums and archives. Ariadne, (22). Retrieved from http://www.ariadne.ac.uk/ issue22/dempsey/

Deng, S., \& Xia, S. (2020). Mapping the interdisciplinarity in information behavior research: a quantitative study using diversity measure and co-occurrence analysis. Scientometrics. doi:10.1007/ s11192-020-03465-x 
Franciska, C., \& BBC Indonesia. (2017). Tentang Ahok, Anies, dan Pilkada Jakarta yang dibumbui "seribu hoax." Retrieved December 23, 2018, from https://www.bbc.com/indonesia/trensosial39618703

IFLA. (2017). How to spot fake news [infographic]. IFLA. IFLA. Retrieved from https://www.ifla.org/publications/node/111 74

IFLA. (2018). IFLA Statement on fake news. Retrieved December 23, 2018, from https://www.ifla.org/publications/node/67 341

Johnson, B. (2017). Information literacy is dead: The role of libraries in a post-truth world. Computers in Libraries; Westport, 37.2(March), 12-15.

Laybats, C., \& Tredinnick, L. (2016). Post truth, information, and emotion. Business Information Review, 33(4), 204-206. doi:10.1177/0266382116680741

Lor, P. J. (2018). Democracy, information, and libraries in a time of post-truth discourse. Library Management, 39(5), 307-321. doi:10.1108/LM-06-2017-0061

Martin, R. S. (2007). Intersecting missions, converging practice. RBM: A Journal of Rare Books, Manuscripts, and Cultural Heritage, 8(1), 80-88. doi:10.5860/ rbm.8.1.281

McIntyre, L. (2018). Post-truth. Cambridge, MA: MIT Press.

Nathaniel, F. (2019). Alasan triawan munaf sebar video sejarah kontroversial - Tirto.ID. Retrieved from https://tirto.id/alasantriawan-munaf-sebar-video-sejarahkontroversial-egtB

National Library Board. (2013). S.U.R.E. Campaign | S.U.R.E. Retrieved from https://sure.nlb.gov.sg/about-us/surecampaign/

Oxford Dictionaries. (2016). Word of the year 2016: Post-truth. Retrieved December 22, 2018 , from ht ps:// en.oxforddictionaries.com/word-of-theyear/word-of-the-year-2016
Oxford Dictionary. (2018). Misinformation | Definition of Misinformation by Lexico. Retrieved from https://www.lexico.com/ en/definition/misinformation

Paré, G., \& Kitsiou, S. (2016). Methods for literature reviews. In F. Lau \& C. Kuziemsky (Eds.), Handbook of eHealth Evaluation: An Evidence-based Approach (pp. 157-179). Victoria: University of Victoria. Retrieved from https:// www.ncbi.nlm.nih.gov/books/NBK48158 3/

Rochlin, N. (2017). Fake news: Belief in posttruth. Library Hi Tech, 35(3), 386-392. doi:10.1108/LHT-03-2017-0062

Rubin, R. E. (2016). Foundations of library and information science (4th ed.). Chicago: Neal-Schuman.

Smiraglia, R. P. (2014). Cultural synergy in information institutions. New York, NY: Springer New York. doi:10.1007/978-14939-1249-0

Solihin, L., Utama, B., Pratiwi, I., \& Novirina. (2019). Indeks aktivitas literasi membaca 34 Provinsi. Jakarta: Pusat Penelitian Kebijakan Pendidikan dan Kebudayaan, Badan Penelitian dan Pengembangan, Kementerian Pendidikan dan Kebudayaan RI. Retrieved from http://repositori. kemdikbud.go.id/13033/1/Puslitjakdikbud Indeks Aktivitas Literasi Membaca 34 Provinsi

Stieglitz, S., \& Dang-Xuan, L. (2013). Emotions and information diffusion in social media-sentiment of microblogs and sharing behavior. Journal of Management Information Systems, 29(4), 217-248. doi:10.2753/MIS0742-1222290408

Sweeny, K., Melnyk, D., Miller, W., \& Shepperd, J. A. (2010). Information avoidance : Who, what, when, and why. Review of General Psychology, 14(4), 340-353. doi:10.1037/a0021288

Tan, S. S.-L., \& Goonawardene, N. (2017). Internet health information seeking and the patient-physician relationship: A systematic review. Journal of Medical Internet Research, 19(1), e9. doi:10.2196/jmir.5729 
Taum, Y. Y. (2020). Dynamical of the truth: Political poetry contestation during Jakarta Gubernatorial Election 2016-2019. Journal of Advanced Research in Dynamical and Control Systems, 12(7), 674-685. doi:10.5373/JARDCS/V12I7/ 20202050
Wahyuni, T. S. (2019). Perilaku penemuan informasi kesehatan oleh orang tua anak penderita leukemia di RSUD Dr. Soetomo Surabaya. Universitas Airlangga. Retrieved from http://repository. unair.ac.id/81337/ 